\title{
Kajian Hukum Kualifkasi Sanksi Kebiri Kimia Sebagai Sanksi Tindakan dalam Hukum Pidana di Indonesia
}

\author{
Tantimin \\ Fakultas Hukum, Universitas Internasional Batam, Indonesia \\ Correspondence email: tantimin@ gmail.com
}

\begin{abstract}
Abstrak. Sanksi kebiri merupakan tindakan yang diberikan kepada pelaku kejahatan seksual terhadap anak, di samping pengenaan sanksi pidana penjara dan denda. Adapun tujuan dari artikel ini adalah untuk mengetahui perbedaan mendasar antara sanksi pidana dengan sanksi tindakan, mengetahui kedudukan sanksi kebiri sebagai sanksi tindakan dalam hukum pidana serta menganalisa sanksi kebiri tidak berlaku bagi anak sebagai pelaku kejahatan seksual. Penelitian ini menggunakan penelitian hukum doktrinal. Sumber informasi hukum menggunakan bahan hukum primer (peraturan dan dokumen relevan) untuk selanjutnya dilakukan analisis secara kualitatif. Pendekatan yang digunakan adalah perundang-undangan, konseptual, dan analisis dalam membantu pemecahan rumusan masalah. Hasil penelitian memperlihatkan bahwa, sanksi pidana dan sanksi tindakan sekilas sering samar untuk dibedakan, namun dalam tataran ide dasar, sangat jelas perbedaannya diantara kedua jenis sanksi tersebut. Sifat reaktif terhadap suatu perbuatan terdapat pada sanksi pidana yang berkonotasi pada pemberian suatu pernderitaan, sedangkan sifat antisipatif terhadap pelaku perbuatan terdapat pada sanksi tindakan yang berkonotasi pada pemberian suatu pemulihan. Kedudukan sanksi kebiri dalam sistem pemidanaan di Indonesia bukanlah sebagai pidana pokok, tambahan maupun pemberatan, namun termasuk sanksi tindakan. Tindakan berupa kebiri kimia dikecualikan bagi pelaku anak.
\end{abstract}

Kata kunci: Kualifikasi; Sanksi Kebiri; Sanksi Tindakan; Hukum Pidana

Abstract. Castration is an action given to perpetrators of sexual crimes against children, in addition to imprisonment and fines. The purpose of this article is to find out the basic differences between criminal sanctions and action sanctions, to know the position of castration as an action sanction in criminal law and to analyze the castration penalty does not apply to children as perpetrators of sexual crimes. This research uses doctrinal legal research. Sources of legal information use primary legal materials (regulations and relevant documents) for further qualitative analysis. The approach used is statutory, conceptual, and analysis to help solve the problem formulation. The results of the research show that, at first glance, criminal sanctions and sanctions are often vague to distinguish, but at the level of basic ideas, there are very clear differences between the two types of sanctions. The reactive nature of an act is contained in the criminal sanction which connotes giving an affliction, while the anticipatory nature of the perpetrator of the act is contained in the sanction of action which connotes giving a remedy. The position of castration in the criminal system in Indonesia is not a principal, additional or a burden, but includes a sanction of action. Actions in the form of chemical castration are exempted for child offenders.

Keywords: Qualifications; Castration Sanctions; Action Sanctions; Criminal Law

\section{PENDAHULUAN}

Berdasarkan Undang-Undang Dasar Negara Republik Indonesia Tahun 1945 (UUD NRI 1945), disebutkan bahwa negara menjamin hak anak atas kelangsungan hidup, tumbuh dan berkembang, serta perlindungan dari kekerasan dan diskriminasi. Seiring dengan cepatnya laju perkembangan zaman dan dampak negatif dari perkembangan teknologi informasi dan komunikasi, tindak pidana kekerasan terhadap anak semakin meningkat tajam khususnya kekerasan seksual. ${ }^{1}$

Lahirnya Undang-Undang Nomor 23 Tahun 2002 tentang Perlindungan Anak telah diubah melalui UndangUndang Nomor 35 Tahun 2014 tentang Perubahan atas Undang-Undang Nomor 23 Tahun 2002 tentang Perlindungan Anak yang salah satu perubahannya memfokuskan kepada pelaku tindak pidana kekerasan seksual terhadap anak dengan adanya pemberatan sanksi pidana. Akan tetapi, adanya perubahan dari undang-undang tersebut masih belum bisa menurunkan tingkat kekerasan seksual terhadap anak secara berarti. Maka dari itu, Negara diharuskan dapat mengambil suatu langkah ataupun strategi yang dinilai optimal dan komprehensif dengan tidak hanya memberikan pemberatan sanksi pidana saja kepada pelaku, tetapi juga melaksanakan bentuk pencegahan (preventif) dengan memberikan tindakan berupa sanksi kebiri kimia, yaitu dengan pemasangan alat pendeteksi elektronik dan rehabilitasi bagi pelaku kekerasan seksual terhadap anak. ${ }^{2}$

\section{${ }^{1}$ Sri Sutatiek, Rekonstruksi Sistem Sanksi dalam Hukum Pidana Anak di Indonesia, (Yogyakarta: Pressindo, 2013), hlm.} 59.

${ }^{2}$ Nur Hafizal Hasanah, \& Eko Soponyono. "Kebijakan Hukum Pidana Sanksi Kebiri Kimia dalam Perspektif HAM dan Hukum Pidana Indonesia." Jurnal Magister Hukum Udayana (Udayana Master Law Journal) Vol.7, No.3 (2018): 305-317, hlm. 307. 
Menanggapi fenomena atau gejala kekerasan seksual terhadap anak dengan adanya pemberian efek jera kepada pelaku, serta dapat mencegah terjadinya tindak pidana kekerasan seksual terhadap anak. Presiden telah menetapkan "Peraturan Pemerintah Pengganti Undang-Undang No. 1 Tahun 2016 tentang Perubahan Kedua Atas Undang-Undang Nomor 23 Tahun 2002 tentang Perlindungan Anak" yang selanjutnya disahkan menjadi Undang-Undang melalui "Undang-Undang No. 17 Tahun 2016 Tentang Penetapan Peraturan Pemerintah Pengganti Undang-Undang Nomor 1 Tahun 2016 Tentang Perubahan Kedua Atas Undang-undang Nomor 23 Tahun 2002 Tentang Perlindungan Anak Menjadi Undang-Undang" (UU Perlindungan Anak). ${ }^{3}$

Materi muatan undang-undang ini sejatinya memuat beberapa hal yakni adanya suatu ketentuan sanksi tindakan berupa kebiri kimiawi yangdiatur dalam Pasal 81 ayat (7) UU Perlindungan Anak, dengan tujuan untuk mengurangi tingkat kekerasan seksual terhadap anak dan membuat efek jera bagi pelaku. Undang-undang ini juga mengatur tentang pemberatan terhadap hukuman pelaku kejahatan seksual, khususnya terhadap anak. dalam undang-undang tersebut mengatur adanya pidana dan tindakan. Penulis berfokus kepada sanksi tindakan. Tindakan yang dimaksud dalam undang-undang tersebut menyatakan bahwa pelaku yang melakukan tindak pidana bisa diberi sanksi tindakan berupa pelaksanaan kebiri kimia disertai dengan rehabilitasi.

Sanksi kebiri kimia merupakan suatu tindakan dengan menyuntikan suatu zat anti-testosteron ke dalam tubuh pria agar dapat menurunkan kadar hormon testosteron, "Testosteron itu adalah hormon yang berperan dalam beragam fungsi, salah satunya fungsi seksual". Maksudnya, hormon testosteron akan berakibat pada gairah seksual seorang pria. Berdasarkan keterangan dari Ketua Bagian Andrologi dan Seksologi Fakultas Kedokteran Universitas Udayana, Denpasar, Wimpie Pangkahila menyampaikan, istilah kebiri di dalam dunia kedokteran itu dikenal dengan nama kastrasi. Kebiri dinilai tidak lagi dilakukan dengan cara membuang testi, namun bisa dilakukan secara kimia. Adapun prosesnya dapat dilakukan dengan cara memberikan pil maupun menyuntikan anti andarogen. Hormon antiandrogen itu artinya anti-hormon laki-laki dengan memberikan obat antiandrogen ini dapat menyebabkab pria kekurangan hormon testosteron, sehingga berakibat pada tidak adanya keinginan seksual. ${ }^{4}$

Pengkualifikasian kebiri kimiawi sebagai sanksi tindakan menimbulkan konsekuensi yakni memulihkan (efek positif) dan bukan menderitakan (efek negatif) yang sesungguhnya merupakan ciri khas dari sanksi pidana. Namun dalam kenyataannya kebiri kimiawi malah menimbulkan efek negatif pada diri pelaku setelah menerima sanksi kebiri kimiawi tersebut. Kekeliruan pengkualifikasian sanksi tindakan kebiri kimiawi ini berimplikasi pada kekaburan dalam memandang apakah tujuan dari sanksi tindakan kebiri kimiawi memberikan pemulihan atau penderitaan.

Kebiri kimia sudah dinilai sebagai tindakan kekerasan dan dianggap bertentangan dengan UUD NRI 1945, yakni hak untuk tidak disiksa, dan hak untuk bebas dari penyiksaan atau perlakuan yang merendahkan derajat martabatnya sebagai manusia. Bukan itu saja, pemberlakuan tindakan kebiri kimia hanya berpusat pada pembalasan pelaku bukan kepada perbaikan atau pemulihan. Tindakan kebiri seolah-olah kembali kepada zaman kolonial yang berorientasi pada pembalasan, padahal Indonesia sudah lama meninggalkan teori pembalasan, Indonesia saat ini berorientasi pada tujuan pemidanaan yaitu untuk memperbaiki pribadi pelaku itu sendiri, selain memperhatikan kepentingan korban.

\section{METODE}

Penelitian ini menggunakan penelitian hukum doktrinal. Sumber informasi hukum menggunakan bahan hukum primer (peraturan dan dokumen relevan) untuk selanjutnya dilakukan analisis secara kualitatif. ${ }^{5}$ Pendekatan yang digunakan adalah perundang-undangan, konseptual dan analisis dalam membantu pemecahan rumusan masalah. ${ }^{6}$ Sumber data penelitian ini, terdiri dari bahan hukum primer, bahan hukum sekunder untuk dilanjutkan dengan menganalisis secara keseluruhan, terhadap peraturan perundang-undangan, literatur, data, dan beberapa dokumen yang terkait, serta bahan hukum tersier untuk menjelaskan dan membantu dalam menganalisis bahan hukum primer maupun sekunder. ${ }^{7}$

3 Fitriani Aulia Rizka, Peringatan 30 Tahun Ratifikasi Konvensi Hak Anak, https://www.tagar.id/peringatan-30-tahunratifikasi-konvensi-hak-anak, Diakses pada Tanggal 13 Desember 2020.

${ }^{4}$ Nur Hafizal Hasanah \& Eko Soponyono. Op.Cit., hlm. 309.

${ }^{5}$ Febri Jaya. "Urgensi Pembatasan Pemilikan dan Penguasaan Tanah Untuk Rumah Tinggal." Legalitas: Jurnal Hukum 12.2 (2020): 198-209, hlm. 200.

${ }^{6}$ Sahuri Lasmadi, dkk. "Islamic Criminal Law Review on the Duality of Principles of Legality in the Draft of Indonesia Criminal Law Code", International Journal of Innovation, Creativity and Change Vol. 14. No.2, (2020): 942-958, hlm. 947.

${ }^{7}$ Syukri Kurniawan, Hari Sutra Disemadi, \& Ani Purwanti. "Urgensi Pencegahan Tindak Pidana Curang (Fraud) Dalam Klaim Asuransi." Halu Oleo Law Review Vol.4, No.1 (2020): 38-53, hlm. 39. 


\section{HASIL DAN PEMBAHASAN}

\section{Perbedaan antara Sanksi Pidana dan Sanksi Tindakan dalam Hukum Pidana di Indonesia}

Disebut sebagai hukum yang sesungguhnya, berasal dari kata straf (Belanda), pidana pada hakekatnya merupakan kerugian dalam bentuk penderitaan istimewa (bijzonder leed) yang ditimpakan negara atau lembaga negara secara sengaja (sifat negatif) ${ }^{8}$, terhadap individu yang telah melakukan pelanggaran terhadap hukum. Pelanggaran yang dimaksud dilakukan kepada mereka yang lemah secara fisik, pikiran, ataupun pengalaman. ${ }^{9}$ Dikatakan bahwa hukum pidana sendiri memiliki 2 (dua) fungsi yakni pertama fungsi umum untuk menjaga ketertiban umum dan yang kedua fungsi khusus untuk melindungi kepentingan hukum. ${ }^{10}$

Menentukan tujuan penjatuhan sanksi dalam hukum pidana (pemidanaan), hal itu merupakan suatu yang dilematis terkhusus dalam menentukan pemidanaan sebagai suatu pembalasan ataukah sebagai pencegahan sosial.Berkaitan dengan itu, terdapat dua teori yang memiliki pengaruh moral yang berbeda antara satu dengan yang lainnya, yaitu teori retributif yang melihat pemidanaan atas suatu dasar tanggung jawab moral dari prilaku yang menyimpang, dan teori ultilitarian yang melihat pemidanaan atas dasar perbaikan sikap serta pencegahan kemungkinan melakukan perbuatan serupa. ${ }^{11}$

Perkembangannya, orientasi pemidanaan dipengaruhi oleh adanya 3 (tiga) jenis aliran yakni berawal dari munculnya aliran klasik yang berkembang pada abad XVIII yang memiliki paham indeterminisme. ${ }^{12}$ Aliran klasik mengenal adanya sebutan sanksi pidana yang diidentikkan sebagai sebuah sarana pembalasan yang sebanding dengan "berat atau ringannya suatu perbuatan yang dilakukan (backward looking)", dengan berorientasi "pada perbuatan dan bukan pada pelakunya (daad-strafrecht)". ${ }^{13}$ Aliran klasik kemudian bergeser dengan hadirnya paradigma pemidanaan baru yang memiliki paham determinisme. Aliran ini dikenal dengan aliran modern yang mengenal adanya sebutan sanksi tindakan yang menitikberatkan pada faktor pemulihan, rehabilitasi serta perbaikan karakter dari seorang manusia (forward looking), dengan berorientasi pada pelaku (daderstrafrecht). Selanjutnya aliran Modern digantikan dengan aliran neoklasik yang menegaskan proses pemidanaan berbasis pembalasan serta rehabilitasi yang dikenal dengan istilah double track system atau sistem dua jalur, yang mengenal adanya sebutan sanksi pidana dan sanksi tindakan, dengan berorientasi pada pelaku dan perbuatannya (daad-dader strafrecht). ${ }^{14}$

Terdapat beberapa pengaturan sanksi pidana dan sanksi tindakan di dalam peraturan perundang-undangan di Indonesia diantaranya "Undang-Undang No. 3 Tahun 1997 tentang Pengadilan Anak", "Undang-Undang No.32 Tahun 2009 tentang Perlindungan dan Pengelolaan Lingkungan Hidup" dan "Undang-Undang No. 35 Tahun 2009 Tentang Narkotika" serta "Rancangan Undang-undang Kitab Undang-Undang Hukum Pidana" (RUU KUHP). Berdasarkan Kitab Undang-Undang Hukum Pidana (KUHP) pengaturan tentang sanksi pidana pada Pasal 10 KUHP yang mencakup pidana pokok dan pidana tambahan. Pidana pokok yang terdiri dari pidana mati, pidana penjara, pidana kurungan, pidana denda dan pidana tutupan. Sedangkan, pidana tambahan yang terdiri dari pencabutan hak-hak tertentu, perampasan barang-barang tertentu dan pengumuman putusan hakim. Adapun, sanksi tindakan diatur di dalam Pasal 44 KUHP yang hanya dapat dikenakan kepada orang yang tidak mampu bertanggung jawab karena cacat jiwanya. Maka dari itu, dikenakan tindakan berupa dimasukkan ke dalam rumah sakit jiwa.

Pengaturan mengenai "sanksi pidana dan sanksi tindakan dalam peraturan perundang-undangan di luar KUHP", diantaranya terdapat di dalam Undang-Undang Nomor 3 Tahun 1997 tentang Pengadilan Anak (UU Pengadilan Anak) menganut konsep double track system dalam stelsel sanksinya. Disebutkan di dalam Pasal 22 UU Pengadilan Anak bahwa anak nakal bisa dijatuhi pidana maupun tindakan menurut undang-undang ini. UU Pengadilan Anak mengenal konsep double track system dalam stelsel sanksinya. Sanksi pidana diatur dalam Pasal 23 UU Pengadilan anak yang mencakup pidana penjara, pidana kurungan dan pidana denda serta pidana pengawasan untuk pidana tambahan terhadap anak nakal. Kemudian, bisa juga dijatuhkan berupa perampasan barang-barang tertentu atau pembayaran ganti rugi. Terhadap pelaku anak tidak ada pidana mati dan pidana seumur hidup, sedangkan sanksi tindakan untuk pelaku anak yang melakukan tindak pidana diatur dalam Pasal 24 Ayat (1) dan Ayat (2) UU Pengadilan Anak yaitu "berupa mengembalikan kepada orang tua wali atau orang tua asuh, menyerahkan kepada negara untuk mengikuti pendidikan, pembinaan, dan latihan kerja". Tindakan dapat disertai dengan teguran dan syarat tambahan yang

${ }^{8}$ Febri Jaya. "Perlindungan Hak-Hak Pekerja Perempuan Pasca Revisi Undang-Undang Ketenagakerjaan Dalam Omnibus Law.” Kertha Semaya: Journal Ilmu Hukum 8.12 (2020): 1886-1897, hlm. 1889.

${ }^{9}$ Eddy O.S Hiariej, Prinsip-Prinsip Hukum Pidana: Edisi Revisi, (Yogyakarta: Cahaya Atma Pustaka, 2016), hlm. 28.

${ }^{10}$ Phyllis B. Gerstenfeld, Crime \& Punishment in The United States, Salem Press, Inc, Prasedana, (New Jersey: California Hackensack, 2008), hlm. 743.

${ }^{11}$ Soerjono Soekanto, Faktor-Faktor yang Mempengaruhi Penegakan Hukum, (Jakarta: Rajawali, 1983), hlm. 35.

12 Eddy O.S Hiariej. Op.Cit., hlm. 29.

${ }^{13}$ Sholehuddin, Sistem Sanksi Dalam Hukum Pidana: Ide Dasar Double Track System \& Implementasinya, (Jakarta: PT Raja Grafindo Persada, 2004), hlm. 25.

${ }^{14}$ Sholehuddin. Ibid., hlm. 27. 
ditetapkan oleh hakim. Berdasarkan UU Pengadilan anak, untuk anak nakal yang melakukan tindak pidana maka penerapan sanksi tindakan lebih didahulukan.

Berdasarkan RUU KUHP juga menganut konsep double track system dalam stelsel sanksinya. Hal ini dapat kita lihat dari pejelasan Pasal 101 RUU KUHP yang mengatakan bahwa dalam undang-undang ini menganut double track system. Berdasarkan RUU KUHP lebih mempertegas "batasan antara sanksi pidana dan sanksi tindakan dalam penerapannya. Pengaturan mengenai sanksi dalam RUU KUHP diatur dalam Pasal 65 RUU KUHP yang mengatur tentang pidana pokok berupa pidana penjara, pidana pengawasan, pidana denda, ganti rugi, pidana kerja sosial”.

Pada ranah praktis, sanksi pidana dan sanksi tindakan sekilas sering samar untuk dibedakan, akan tetapi dalam tataran ide dasar, sangat jelas perbedaannya diantara kedua jenis sanksi tersebut. Sanksi pidana beranjak dari ide dasar; "Mengapa pemidanaan diadakan?", sedangkan sanksi tindakan beranjak dari ide dasar; "Untuk apa pemidanaan diadakan?". Dalam hal ini, dapat dikatakan sifat reaktif terhadap suatu perbuatan terdapat pada sanksi pidana yang berkonotasi pada pemberian suatu pernderitaan, sedangkan sifat antisipatif terhadap pelaku perbuatan terdapat pada sanksi tindakan yang berkonotasi pada pemberian suatu pemulihan.

\section{Kedudukan Sanksi Kebiri sebagai Sanksi Tindakan dalam Hukum Pidana}

Hukuman kebiri ini dikenal ada 2 (dua) bentuknya yakni kebiri fisik dan kebiri kimia. Kebiri fisik adalah jenis kebiri berupa pemotongan secara total alat kelamin laki-laki sedangkan kebiri kimia adalah dengan memasukkan sejenis obat dan disuntikkan kepada pelaku kejahatan seksual, dimana obat ini akan menurunkan hasrat libido dari pelaku. ${ }^{15}$

Kebiri kimia merupakan suatu tindakan dengan memasukkan bahan kimia antiandrogen, baik melalui pil atau suntikan ke dalam tubuh pria. Maksud daripada suntikan dalam hukum kebiri kimia adalah untuk memperlemah "hormon testosterone", untuk menghilangkan fungsi hormon sekunder laki-laki. Suntikan bahan kimia antiandrogen oleh Dokter Eka Viora, Wakil Ketua Pengurus Pusat Perhimpunan Dokter Spesialis Kesehatan Jiwa Indonesia (PDSKJI) dikatakan bahwa tidak lain untuk menghilangkan fungsi hormon sekunder laki-laki, selanjutnya dijelaskan bahwa: "Diantaranya akan berpengaruh pada fungsi hormon sekunder laki-lakinya akan jadi hilang, dia akan jadi seperti perempuan. Kalau waria biasanya senang, karena akan muncul sifat-sifat perempuannya. Misalnya payudara bisa membesar, namun tulangnya mudah keropos". ${ }^{16}$

Pengaruh dari zat anti-testosteron hanya bersifat sementara, begitu juga dengan obat-obat kimia lainnya. Zat anti-testosteron tergantung oleh batas waktu. Berdasarkan keterangan dari Dokter Nugroho mengatakan, orang mungkin beranggapan bahwa kebiri kimia sekali suntik selesai, seperti halnya orang yang dikebiri secara fisik dimana mereka harus mendapatkan terus menerus. Selanjutnya, dikatakan bahwa dengan memberikan lebih banyak hormon perempuan ke tubuh pria, produksi hormon testosteron akan menurun dan kehilangan fungsinya. Zat anti-testosteron jika diberikan secara rutin kepada pria yang kadar testosteronnya normal, diprediksi akan mengakibatkan penurunan gairah seksual pria tersebut. Penurunan hormon testosteron tersebut akan berpengaruh ke otak sehingga suasana hati menjadi tidak nyaman serta pemarah. Lalu, dampaknya ke kulit sehingga kulit menjadi kering. Kemudian, otot menjadi mengecil, tulang mudah keropos, serta orang tersebut juga akan sangat lemah. ${ }^{17}$

Pengebirian bedah sudah dikenal sejak abad ke-18 dan 19 di Amerika, dimana seorang pria bernama Dr. Harry Sharp mengebiri hampir 200 (dua ratus) tahanan dengan tujuan untuk mengurangi kemungkinan bahwa mereka akan melakukan kejahatan seksual lagi. Tetapi baru pada tahun 1944 penggunaan terapi hormon muncul sebagai cara untuk menurunkan testosteron dan mengurangi perilaku seksual patogis pada pria. Sanksi kebiri kimia sudah ada di Eropa sejak abad pertengahan. Sampai sekarang sanksi kebiri masih diberlakukan dibeberapa negara seperti Korea Selatan, Rusia, Selandia Baru, Australia, Israel, Ceko, Moldova, Jerman, Estonia, Argentia dan beberapa negara bagian Amerika Serikat ${ }^{18}$

Di Indonesia, dalam penerapan kebiri dilakukan secara kimiawi yang tercantum di dalam "Undang-Undang Nomor 17 Tahun 2016 tentang Penetapan Peraturan Pemerintah Pengganti Undang-Undang Nomor 1 Tahun 2016 tentang Perubahan Kedua atas Undang-Undang Nomor 23 Tahun 2002 tentang Perlindungan Anak" yang telah disahkan menjadi undang-undang pada tanggal 9 November 2016. Adapun perubahan yang dilakukan dalam UndangUndang Nomor 17 Tahun 2016 sebagai berikut:

Pasal 81 mengatur: "(1) Setiap orang yang melanggar ketentuan sebagaimana dimaksud dalam Pasal 76D dipidana dengan pidana penjara paling singkat 5 (lima) tahun dan paling lama 15 (lima belas) tahun dan denda paling banyak Rp5.000.000.000,00 (lima miliar rupiah)”; “(2) Ketentuan pidana sebagaimana dimaksud pada ayat (1) berlaku

${ }^{15}$ Ratih Probosiwi \& Daud Bahransyaf. "Pedofilia dan Kekerasan Seksual: Masalah dan Perlindungan Terhadap Anak", Sosio Informa Vol.1, No.1, (2015): 29-40, hlm. 36.

${ }^{16}$ Ratih Probosiwi \& Daud Bahransyaf. Ibid., hlm. 37.

${ }^{17}$ Ratih Probosiwi \& Daud Bahransyaf. Ibid., hlm. 39.

${ }^{18}$ Mike C. Materni. "Criminal Punishment and the Pursuit of Justice", British Journal of American Legal Studies Vol.2, No.1, (2013): 263-304, hlm. 271. 
pula bagi setiap Orang yang dengan sengaja melakukan tipu muslihat, serangkaian kebohongan, atau membujuk Anak melakukan persetubuhan dengannya atau dengan orang lain”; “(3) Dalam hal tindak pidana sebagaimana dimaksud pada ayat (1) dilakukan oleh orang tua, wali, orang-orang yang mempunyai hubungan keluarga, pengasuh anak, pendidik, tenaga kependidikan, aparat yang menangani perlindungan anak, atau dilakukan oleh lebih dari satu orang secara bersama-sama, pidananya ditambah $1 / 3$ (sepertiga) dari ancaman pidana sebagaimana dimaksud pada ayat (1)"; "(4) Selain terhadap pelaku sebagaimana dimaksud pada ayat (3), penambahan 1/3 (sepertiga) dari ancaman pidana juga dikenakan kepada pelaku yang pernah dipidana karena melakukan tindak pidana sebagaimana dimaksud dalam Pasal 76D”; "(5) Dalam hal tindak pidana sebagaimana dimaksud dalam Pasal 76D menimbulkan korban lebih dari 1 (satu) orang, mengakibatkan luka berat, gangguan jiwa, penyakit menular, terganggu atau hilangnya fungsi reproduksi, dan/atau korban meninggal dunia, pelaku dipidana mati, seumur hidup, atau pidana penjara paling singkat 10 (sepuluh) tahun dan paling lama 20 (dua puluh) tahun"; "(6) Selain dikenai pidana sebagaimana dimaksud pada ayat (1), ayat (3), ayat (4), dan ayat (5), pelaku dapat dikenai pidana tambahan berupa pengumuman identitas pelaku"; "(7) Terhadap pelaku sebagaimana dimaksud pada ayat (4) dan ayat (5) dapat dikenai tindakan berupa kebiri kimia dan pemasangan cip”; “(8) Tindakan sebagaimana dimaksud pada ayat (7) diputuskan bersama-sama dengan pidana pokok dengan memuat jangka waktu pelaksanaan tindakan"; dan "(9) Pidana tambahan dan tindakan dikecualikan bagi pelaku Anak".

Diantara Pasal 81 dan Pasal 82 diselipkan 1 (satu) pasal yaitu Pasal 81A. Pasal 81A mengatur: “(1) Tindakan sebagaimana dimaksud dalam Pasal 81 ayat (7) dikenakan untuk jangka waktu paling lama 2 (dua) tahun dan dilaksanakan setelah terpidana menjalani pidana pokok"; “(2) Pelaksanaan tindakan sebagaimana dimaksud pada ayat (1) di bawah pengawasan secara berkala oleh kementerian yang menyelenggarakan urusan pemerintahan di bidang hukum, sosial, dan kesehatan”; "(3) Pelaksanaan kebiri kimia disertai dengan rehabilitasi”; dan "(4) Ketentuan lebih lanjut mengenai tata cara pelaksanaan tindakan dan rehabilitasi diatur dengan Peraturan Pemerintah".

Ketentuan Pasal 82 diubah sehingga mengatur: "(1) Setiap orang yang melanggar ketentuan sebagaimana dimaksud dalam Pasal 76E dipidana dengan pidana penjara paling singkat 5 (lima) tahun dan paling lama 15 (lima belas) tahun dan denda paling banyak Rp5.000.000.000,00 (lima miliar rupiah) (Catatan: Bunyi pasal 76E dalam UU 23/2004 berbunyi: "Setiap Orang dilarang melakukan Kekerasan atau ancaman Kekerasan, memaksa, melakukan tipu muslihat, melakukan serangkaian kebohongan, atau membujuk Anak untuk melakukan atau membiarkan dilakukan perbuatan cabul")"; "(2) Dalam hal tindak pidana sebagaimana dimaksud pada ayat (1) dilakukan oleh orang tua, wali, orang-orang yang mempunyai hubungan keluarga, pengasuh anak, pendidik, tenaga kependidikan, aparat yang menangani perlindungan anak, atau dilakukan oleh lebih dari satu orang secara bersama-sama, pidananya ditambah 1/3 (sepertiga) dari ancaman pidana sebagaimana dimaksud pada ayat (1)"; "(3) Selain terhadap pelaku sebagaimana dimaksud pada ayat (2), penambahan 1/3 (sepertiga) dari ancaman pidana juga dikenakan kepada pelaku yang pernah dipidana karena melakukan tindak pidana sebagaimana dimaksud dalam Pasal 76E”; "(4) Dalam hal tindak pidana sebagaimana dimaksud dalam Pasal 76E menimbulkan korban lebih dari 1 (satu) orang, mengakibatkan luka berat, gangguan jiwa, penyakit menular, terganggu atau hilangnya fungsi reproduksi, dan/atau korban meninggal dunia, pidananya ditambah $1 / 3$ (sepertiga) dari ancaman pidana sebagaimana dimaksud pada ayat (1)"; "(5) Selain dikenai pidana sebagaimana dimaksud pada ayat (1) sampai dengan ayat (4), pelaku dapat dikenai pidana tambahan berupa pengumuman identitas pelaku"; “(6) Terhadap pelaku sebagaimana dimaksud pada ayat (2) sampai dengan ayat (4) dapat dikenai tindakan berupa rehabilitasi dan pemasangan cip"; "(7) Tindakan sebagaimana dimaksud pada ayat (6) diputuskan bersama-sama dengan pidana pokok dengan memuat jangka waktu pelaksanaan tindakan"; dan "(8) Pidana tambahan dikecualikan bagi pelaku anak".

Di antara Pasal 82 dan Pasal 83 disisipkan 1 (satu) pasal yakni Pasal 82A yang berbunyi sebagai berikut: “(1) Tindakan sebagaimana dimaksud dalam Pasal 82 ayat (6) dilaksanakan selama dan/atau setelah terpidana menjalani pidana pokok"; "(2) Pelaksanaan tindakan sebagaimana dimaksud pada ayat (1) di bawah pengawasan secara berkala oleh kementerian yang menyelenggarakan urusan pemerintahan di bidang hukum, sosial, dan kesehatan"; dan "(3) Ketentuan lebih lanjut mengenai tata cara pelaksanaan tindakan diatur dengan Peraturan Pemerintah".

Merujuk pada ketentuan Pasal 81 ayat (7) UU Perlindungan Anak, adanya memuat sanksi kebiri kimiawi sebagai tindakan medis yang tergolong jenis penghukuman terhadap badan (corporal punishment). Nyatanya penjatuhan sanksi kebiri kimiawi tersebut hanyalah menghilangkan dorongan seksual secara sementara (temporer) dan tidak bersifat menyembuhkan. Penelitian yang telah dilakukan oleh dr. Boyke menjelaskan bahwa sanksi kebiri kimiawi malah akan menimbulkan perubahan karakter tubuh yang menyerupai perempuan, perontokan bulu, yang selanjutnya berdampak pada melemahnya organ vital lainnya sehingga dapat terjadi osteoforosis, badan membungkuk, pompa darah jantung yang melemah, dan kemungkinan timbulnya serangan jantung. Tidak hanya berdampak pada fisik, tetapi efek dari kebiri kimiawi juga ternyata akan mempengaruhi mental orang tersebut. Dampak psikologis ini 
disebabkan karena memikirkan perubahan yang terjadi pada dirinya yang bisa berakibat pada kondisi depresi, sehingga memunculkan suatu kemungkinan untuk membuat keputusan melakukan bunuh diri. ${ }^{19}$

Dalam hal ini, terlihat bahwa sanksi kebiri kimiawi seakan sebagai upaya balas dendam dan dijatuhkan berdasarkan pertimbangan biologis semata dengan mengatasnamakan kepentingan korban dan agar tidak menimbulkan korban lainnya, tetapi tidak memikirkan bagaimana efek berlanjutnya dan seakan menjadi boomerang yang menimbulkan adanya korban-korban baru yakni dalam hal ini pelaku pedofilia itu sendiri. Penjatuhan sanksi kebiri kimiawi juga tidak menjamin bahwa agresifitas yang dimiliki oleh pelaku pedofilia akan hilang atau berkurang, selama tidak diobatinya kondisi mental pelaku pedofilia. Sanksi kebiri kimiawi malah kemungkinan besar menimbulkan rasa dendam dan perilaku lebih nekat karena penyiksaan yang dialami oleh pelaku pedofilia. Kejahatan seksual bukanlah hanya soal penetrasi. ${ }^{20}$ Pelaku bisa saja menggunakan cara lain untuk memenuhi hastrat seksual dan dendamnya, bisa dengan menggunakan botol, kayu, dan alat bantu seksual lainnya.

Berdasarkan ketentuan Pasal 81 ayat (8) UU Perlindungan Anak menentukan bahwa sanksi tindakan kebiri kimiawi diputuskan secara "bersama-sama" dengan pidana pokoknya. Frasa bersama-sama dalam ketentuan tersebut seakan membuktikan tambah amat rentan dimuatnya sanksi kebiri kimiawi dalam penerapannya terutama dalam mengantisipasi terjadinya double punishment yang tidak sesuai dengan prinsip double track system, dikarenakan secara esensial sanksi tindakan kebiri kimiawi telah berbeda dengan alasan utama (ratio d' etre) tindakan dalam hukum pidana. Tindakan bertujuan untuk memberikan keuntungan/memperbaiki yang bersangkutan, sedangkan sanksi kebiri kimiawi bukanlah merupakan suatu bentuk sarana rehabilitasi yang bisa menyembuhkan pedofilia yang merupakan penyimpangan seksualitas. ${ }^{21}$

Hal lainnya lagi yakni bahwa pemidanaan bukan hanya upaya menyadarkan pelaku agar menyesali perbuatannya, tetapi juga agar dapat mengembalikan pelaku menjadi warga masyarakat yang baik, dengan taat dengan hukum dan menjungjung tinggi adanya nilai-niai moral, sosial dan keagamaan, guna menuju kehidupan masyarakat yang diinginkan yakni aman, tertib, dan damai. Sejalan dengan itu, perlu diingat kembali bahwa paradigma baru pemidanaan di Indonesia sudah mengalami pergeseran yang awalnya dari retributif sekarang kearah restoratif atau model keseimbagan kepentingan. ${ }^{22}$ Konsep restoratif justice ini pada hakikatnya tetap memberikan penegakan hukum ("law enforcement") kepada pelaku tetapi yang mengandung anasir mendidik sehingga menghasilkan manfaat baik kepada pelaku, korban, dan masyarakat dalam arti yang luas. ${ }^{23}$

Apabila ditinjau dari teori kebijakan hukum pidana, selain dalam menjalankan suatu politik (kebijakan) hukum pidana atau istilah lainnya sering disebut "penal policy", juga mengadakan pemilihan dalam membuat dan merumuskan guna mencapai hasil dari perundangan-undangan pidana yang paling baik dimasa yang akan datang seperti apa yang dicita-citakan (ius constituendum) dengan melakukan pembaharuan hukum, yang mana dalam arti agar memenuhi syarat keadilan serta daya guna. ${ }^{24} \mathrm{Hal}$ ini hendak melibatkan hukum pidana dalam usaha menangani segi negatif dari adanya perkembangan masyarakat, maka dari hubungan keseluruhan kebijakan kriminal harus merupakan bagian integral dari suatu rencana perlindungan masyarakat ("social defence") yang merupakan upaya menciptakan kesejahteraan masyarakat ("social walfare"). Pembaharuan hukum pidana tidaklah dapat dibenarkan, apabila suatu pembaharuan hukum pidana yang pada dasarnya merupakan upaya mengefektifkan penegakan hukum dengan memperbaharui substansi hukumnya (legal substance). Jika tujuan nilai dari hukum pidana yang di citacitakan tetap sama dengan tujuan dari hukum pidana yang terdahulu. ${ }^{25}$

\section{Sanksi Kebiri Tidak Berlaku Bagi Anak Pelaku Kejahatan Seksual di Indonesia}

Tindak pidana kekerasan seksual terhadap anak dinilai merupakan suatu bentuk ancaman yang berarti dalam menghambat pertumbuhan dan perkembangan anak. Kekerasan (Violence) adalah serangan atau invasi (assault)

19 Maria Amanda. Penjelasan Dokter Boyke tentang Dampak Kebiri Kimiawi, https://lifestyle.okezone.com/read/2016/06/01/481/1403478/penjelasandokter-boyke-tentang-dampak-kebiri-kimia, Diakses Pada Tanggal 14 Desember 2020.

${ }^{20}$ Supriyadi Widodo, dkk., Menguji Euforia Kebiri: Catatan Kritis atas Rencana Kebijakan Kebiri (Chemical Costration) bagi Pelaku kejahatan Seksual Anak di Indonesia, (Jakarta Selatan: Aliansi 99 Tolak Perppu Kebiri 2016), hlm. 22.

${ }^{21}$ Gusti Ngurah Yulio. "Tinjauan Yuridis Terhadap Hukuman Kebiri Terhadap Pelaku Kekerasan Seksual Kepada Anak", Jurnal Kertha Wicara Vol.7, No.2, (2018): 1-15, hlm. 9.

${ }^{22}$ Eva Achjani Zulfa, "Pergeseran Paradigma Pemidanaan Di Indonesia", Jurnal Hukum dan Pembangunan Vol.36, No.3, (2006): 389-403, hlm. 399.

23 Amboro, Yudhi Priyo, and Fandias Fandias. "Tinjauan Yuridis Tindak Pidana Pencucian Uang Dalam Tindak Pidana Korupsi di Indonesia.” Journal of Judicial Review 16.1 (2017): 74-89., hlm. 75.

24 Sudarto, Hukum dan Hukum Pidana, (Bandung: Alumni, 2005), hlm. 19.

${ }^{25}$ Barda Nawawi Arief, Bunga Rampai Kebijakan Hukum Pidana, Perkembangan Penyusunan Konsep KUHP baru, (Jakarta: Kencana Prenada Media Group, 2011), hlm. 30. 
terhadap fisik maupun integritas mental psikologis seseorang. ${ }^{26}$ Perkara tindak pidana kekerasan seksual berupa pemerkosaan terhadap anak, perlu mendapatkan perhatian dari berbagai pihak. Mengingat usia anak yang relatif sangat muda, kebanyakan dari mereka yang menjadi korban pemerkosaan belum mengetahui atau mengerti terhadap perbuatan yang menimpa dirinya. Tanpa disadari bahkan mereka telah menjadi korban dari suatu tindak pidana pemerkosaan, karena anak tidak menyadari dan tidak mengerti mengenai arti perbuatan yang dilakukan oleh pelaku pemerkosaan terhadap mereka. ${ }^{27}$

Berdasarkan undang-undang, tidak ada terminologi "Pelaku kejahatan di bawah umur", yang ada adalah "anak yang berkonflik dengan hukum". Sebagaimana terdapat dalam Undang-Undang Nomor 11 Tahun 2012 tentang Sistem Peradilan Pidana Anak (UU SPPA), disebutkan bahwa "Anak yang berkonflik dengan hukum atau yang disebut anak adalah anak yang telah berumur 12 (dua belas) tahun, tetapi belum berumur 18 (delapan belas) tahun yang diduga melakukan tindak pidana". Kemudian mengenai Peraturan Pemerintah Pengganti Undang-Undang Nomor 1 Tahun 2016 tentang Perubahan Kedua Atas Undang-Undang Nomor 23 Tahun 2002 tentang Perlindungan Anak. Sanksi kebiri ini diberikan sebagai bentuk tindakan kepada pelaku kejahatan seksual terhadap anak, di samping pengenaan sanksi pidana penjara dan denda, yang diatur dalam Pasal 81 jo. Pasal 76D UU Perlindungan Anak.

Selengkapnya Pasal 81 yang mengatur mengenai sanksi kebiri adalah sebagai berikut: “(1) Setiap orang yang melanggar ketentuan sebagaimana dimaksud dalam Pasal 76D dipidana dengan pidana penjara paling singkat 5 (lima) tahun dan paling lama 15 (lima belas) tahun dan denda paling banyak Rp5.000.000.000,00 (lima miliar rupiah)"; "(2) Ketentuan pidana sebagaimana dimaksud pada ayat (1) berlaku pula bagi setiap Orang yang dengan sengaja melakukan tipu muslihat, serangkaian kebohongan, atau membujuk Anak melakukan persetubuhan dengannya atau dengan orang lain"; "(3) Dalam hal tindak pidana sebagaimana dimaksud pada ayat (1) dilakukan oleh orang tua, wali, orang-orang yang mempunyai hubungan keluarga, pengasuh anak, pendidik, tenaga kependidikan, aparat yang menangani perlindungan anak, atau dilakukan oleh lebih dari satu orang secara bersama-sama, pidananya ditambah 1/3 (sepertiga) dari ancaman pidana sebagaimana dimaksud pada ayat (1)"; "(4) Selain terhadap pelaku sebagaimana dimaksud pada ayat (3), penambahan 1/3 (sepertiga) dari ancaman pidana juga dikenakan kepada pelaku yang pernah dipidana karena melakukan tindak pidana sebagaimana dimaksud dalam Pasal 76D”; “(5) Dalam hal tindak pidana sebagaimana dimaksud dalam Pasal 76D menimbulkan korban lebih dari 1 (satu) orang, mengakibatkan luka berat, gangguan jiwa, penyakit menular, terganggu atau hilangnya fungsi reproduksi, dan/atau korban meninggal dunia, pelaku dipidana mati, seumur hidup, atau pidana penjara paling singkat 10 (sepuluh) tahun dan paling lama 20 (dua puluh) tahun"; "(6) Selain dikenai pidana sebagaimana dimaksud pada ayat (1), ayat (3), ayat (4), dan ayat (5), pelaku dapat dikenai pidana tambahan berupa pengumuman identitas pelaku"; "(7) Terhadap pelaku sebagaimana dimaksud pada ayat (4) dan ayat (5) dapat dikenai tindakan berupa kebiri kimia dan pemasangan cip"; "(8)Tindakan sebagaimana dimaksud pada ayat (7) diputuskan bersama-sama dengan pidana pokok dengan memuat jangka waktu pelaksanaan Tindakan"; dan “(9) Pidana tambahan dan tindakan dikecualikan bagi pelaku Anak".

Mengenai apakah kepada pelaku kejahatan yang masih tergolong anak akan dikenakan tindakan kebiri juga. Jika kita merujuk pada pasal di atas jelas bahwa tindakan berupa kebiri kimia dikecualikan bagi pelaku anak. Pidana tambahan ini melengkapi pemberatan pidana pokok bagi pelaku kejaahtan seksual pada anak, dengan dampak berat terhadap korban atau jumlah korban lebih dari satu. Pidana pokok tersebut: pidana mati, atau penjara minimal 10 (sepuluh) tahun dan maksimal 12 (dua belas) tahun.

Tindak Pidana kekerasan seksual dan pemerkosan terhadap anak merupakan perbuatan keji yang tidak beradab sehingga dapat merusak kehidupan anak. Pemerintah diharuskan dapat mengambil kebijakan atau tindakan yang tepat dan optimal dalam memberikan hukuman kepada pelaku, agar dapat memberikan pemulihan kepada korban secara menyeluruh serta dapat mencegah kekerasan seksual kepada anak terus berlanjut. Walaupun demikian, kebijakan pencegahan itu harus relevan dengan prinsip hak asasi manusia serta menggambarkan penerapan yang tepat supaya kebijakan tersebut dapat berjalan secara efektif. ${ }^{28}$

\section{SIMPULAN}

Secara esensial, perbedaan mendasar antara sanksi pidana dan sanksi tindakan yakni apabila sanksi pidana mengarah pada suatu penderitaan (backward looking) dengan sifat reaktif yang beranjak dari ide dasar; "Mengapa pemidanaan diadakan?", sedangkan sanksi tindakan mengarah pada pemulihan (forward looking) dengan sifat antisipatif yang beranjak dari ide dasar; "Untuk apa pemidanaan diadakan?". Kedudukan pidana kebiri di dalam

${ }^{26}$ Rusmilawati Windari, \& Azmi Syahputra. "Menakar Aspek Kemanfaatan dan Keadilan Pada Sanksi Kebiri Kimia Terhadap Pelaku Kekerasan Seksual Anak Di Indonesia.” Soumatera Law Review Vol.3, No.2 (2020): 247-264, hlm. 252.

${ }^{27}$ I Nyoman Ngurah Suwarnatha, Tujuan Pemidanaan Sanksi Tindakan Kebiri Kimia Bagi Pelaku Kekerasan Seksual Terhadap Anak, Seminar Nasional Hukum Dan Ilmu Sosial Ke-2, (Denpasar: Fakultas Hukum Universitas Pendidikan Nasional, 2018), hlm. 9.

28 Imelda Yulita Onsu. "Kajian Yuridis Hukum Kebiri Dalam Perspektif Negara Yang Berdasarkan Pancasila", Lex Privatum Vol.3, No.3, (2020): 65-75, hlm. 70. 
sistem pemidanaan Indonesia bukanlah sebagai pidana pokok, tambahan maupun pemberatan, namun termasuk sebagai tindakan. Sanksi kebiri merupakan tindakan yang diberikan kepada pelaku kejahatan seksual terhadap anak, di samping pengenaan sanksi pidana penjara dan denda. Tindakan kebiri kimia kepada pelaku kekerasan seksual dilakukan sebagai upaya pemulihan gangguan seksual pelaku, sehingga bukan sebagai penyiksaan terhadap pelaku. Tindakan berupa kebiri kimia dikecualikan bagi pelaku anak.

Pemerintah melakukan rekonstruksi ketentuan Pasal 81 ayat (7) UU Perlindungan Anak dengan menghilangkan sanksi kebiri kimiawi dengan alasan pertama, tidak sesuai dengan konsepsi sanksi tindakan dan kedua, apabila tetap dipertahankan akan terjadi "double punhisment" yang tidak sesuai dengan prinsip "double track system". Sanksi kebiri lebih tepat dikelompokan sebagai pidana pokok saja. Jika pidana kebiri ditempatkan sebagai pidana tindakan, lalu ditambahkan dengan pidana pokok tentu akan merusak filosofi dari pemidanaan antara bermaksud memberi efek jera atau hendak memulihkan sikap dan keadaan mental pelaku.

\section{DAFTAR PUSTAKA}

\section{Buku}

Arief, Barda Nawawi. Bunga Rampai Kebijakan Hukum Pidana, Perkembangan Penyusunan Konsep KUHP baru, Jakarta: Kencana Prenada Media Group, 2011.

Gerstenfeld, Phyllis B. Crime \& Punishment in The United States, Salem Press, Inc, Prasedana, New Jersey: California Hackensack, 2008.

Hiariej, Eddy O.S. Prinsip-Prinsip Hukum Pidana: Edisi Revisi, Yogyakarta: Cahaya Atma Pustaka, 2016.

Sholehuddin. Sistem Sanksi Dalam Hukum Pidana: Ide Dasar Double Track System \& Implementasinya, Jakarta: PT Raja Grafindo Persada, 2004.

Soekanto, Soerjono. Faktor-Faktor yang Mempengaruhi Penegakan Hukum, Jakarta: Rajawali, 1983.

Sudarto, Hukum dan Hukum Pidana, Bandung: Alumni, 2005.

Sutatiek, Sri. Rekonstruksi Sistem Sanksi dalam Hukum Pidana Anak di Indonesia, Yogyakarta: Pressindo, 2013.

Suwarnatha, I Nyoman Ngurah. Tujuan Pemidanaan Sanksi Tindakan Kebiri Kimia Bagi Pelaku Kekerasan Seksual Terhadap Anak, Seminar Nasional Hukum Dan Ilmu Sosial Ke-2, Denpasar: Fakultas Hukum Universitas Pendidikan Nasional, 2018.

Widodo, Supriyadi. dkk., Menguji Euforia Kebiri: Catatan Kritis atas Rencana Kebijakan Kebiri (Chemical Costration) bagi Pelaku kejahatan Seksual Anak di Indonesia, Jakarta Selatan: Aliansi 99 Tolak Perppu Kebiri, 2016.

\section{Jurnal}

Amboro, Yudhi Priyo, and Fandias Fandias. "Tinjauan Yuridis Tindak Pidana Pencucian Uang Dalam Tindak Pidana Korupsi di Indonesia." Journal of Judicial Review 16.1 (2017): 74-89.

Hasanah, Nur Hafizal., \& Eko Soponyono. "Kebijakan Hukum Pidana Sanksi Kebiri Kimia dalam Perspektif HAM dan Hukum Pidana Indonesia." Jurnal Magister Hukum Udayana (Udayana Master Law Journal) Vol.7, No.3 (2018): 305-317.

Jaya, Febri. "Urgensi Pembatasan Pemilikan dan Penguasaan Tanah Untuk Rumah Tinggal." Legalitas: Jurnal Hukum 12.2 (2020): 198-209.

Jaya, Febri. "Perlindungan Hak-Hak Pekerja Perempuan Pasca Revisi Undang-Undang Ketenagakerjaan Dalam Omnibus Law." Kertha Semaya: Journal Ilmu Hukum 8.12 (2020): 1886-1897.

Kurniawan, Syukri, Hari Sutra Disemadi, \& Ani Purwanti. "Urgensi Pencegahan Tindak Pidana Curang (Fraud) Dalam Klaim Asuransi." Halu Oleo Law Review Vol.4, No.1 (2020): 38-53, hlm. 39.

Lasmadi, Sahuri., dkk. "Islamic Criminal Law Review on the Duality of Principles of Legality in the Draft of Indonesia Criminal Law Code", International Journal of Innovation, Creativity and Change Vol. 14. No.2, (2020): 942-958.

Materni, Mike C. "Criminal Punishment and the Pursuit of Justice", British Journal of American Legal Studies Vol.2, No.1, (2013): 263-304.

Onsu, Imelda Yulita. "Kajian Yuridis Hukum Kebiri Dalam Perspektif Negara Yang Berdasarkan Pancasila", Lex Privatum Vol.3, No.3, (2020): 65-75.

Probosiwi, Ratih., \& Daud Bahransyaf. "Pedofilia dan Kekerasan Seksual: Masalah dan Perlindungan Terhadap Anak", Sosio Informa Vol.1, No.1, (2015): 29-40.

Windari, Rusmilawati., \& Azmi Syahputra. "Menakar Aspek Kemanfaatan dan Keadilan Pada Sanksi Kebiri Kimia Terhadap Pelaku Kekerasan Seksual Anak Di Indonesia." Soumatera Law Review Vol.3, No.2 (2020): 247-264.

Yulio, Gusti Ngurah. "Tinjauan Yuridis Terhadap Hukuman Kebiri Terhadap Pelaku Kekerasan Seksual Kepada Anak", Jurnal Kertha Wicara Vol.7, No.2, (2018): 1-15. 
Zulfa, Eva Achjani. "Pergeseran Paradigma Pemidanaan Di Indonesia", Jurnal Hukum dan Pembangunan Vol.36, No.3, (2006): 389-403.

\section{Website}

Amanda, Maria. Penjelasan Dokter Boyke tentang Dampak Kebiri Kimiawi, https://lifestyle.okezone.com/read/2016/06/01/481/1403478/penjelasandokter-boyke-tentang-dampak-kebirikimia, Diakses Pada Tanggal 14 Desember 2020.

Rizka, Fitriani Aulia. Peringatan 30 Tahun Ratifikasi Konvensi Hak Anak, https://www.tagar.id/peringatan-30-tahunratifikasi-konvensi-hak-anak, Diakses pada Tanggal 13 Desember 2020. 